Saudi Journal of Medical and Pharmaceutical Sciences

Abbreviated Key Title: Saudi J Med Pharm Sci

ISSN 2413-4929 (Print) |ISSN 2413-4910 (Online)

Scholars Middle East Publishers, Dubai, United Arab Emirates

Journal homepage: https://saudijournals.com/sjmps

Original Research Article

\title{
Anti-Plasmodial Activity of Methanol Extract of Ficus sycomorus
}

\author{
Abbas $\mathrm{AY}^{1 *}$, Ladan $\mathrm{MJ}^{1}$, Girei $\mathrm{AM}^{2}$, Achor $\mathrm{M}^{3}$ \\ ${ }^{1}$ Department of Biochemistry, Faculty of Science, Usmanu Danfodiyo University, P.M.B. 2346, Sokoto, Nigeria \\ ${ }^{2}$ National Universities Commision, Abuja Nigeria \\ ${ }^{3}$ Department of Pharmaceutics and Pharmaceutical Microbiology, Usmanu Danfodiyo University, P.M.B. 2346, Sokoto, Nigeria
}

\begin{tabular}{ll}
\hline DOI: $10.36348 /$ sjmps.2020.v06i03.010 & | Received: 16.03 .2020 | Accepted: $23.03 .2020 \mid$ Published: 30.03 .2020 \\
*Corresponding author: Abbas AY &
\end{tabular}

*Corresponding author: Abbas AY

\section{Abstract}

Malaria has been reported to be one of the most debilitating illnesses of all time and is the most common parasitic disease in sub-Saharan Africa. Methanol extract of the four parts of Ficus sycomorus plant (leave, fruits, stem-bark and roots) were screen for in vitro anti-plasmodial activity using Plasmodium falciparum. The $\mathrm{IC}_{50}$ revealed that the fruits and leave extract have an $\mathrm{IC}_{50}>186 \mu \mathrm{g}$ while stem-bark and roots were discovered to be the most active with $\mathrm{IC}_{50} \mathrm{of} 20.4 \mu \mathrm{g}$. In vitro anti-plasmodial activity of organic solvent extracts (Hexane, ethylacetate and saturated butanol) of the methanol root extract revealed $\mathrm{IC}_{50}$ of $40 \mu \mathrm{g}, 20.4 \mu \mathrm{g}$ and $20.4 \mu \mathrm{g}$ respectively. In vivo anti-plasmodial activity of the saturated butanol extract of the root was investigated in albino mice. Thirty (30) mice were inoculated with the parasitized donor erythrocytes containing Plasmodium berghei. One week after parasite inoculation, the animals were randomly distributed into six groups of five mice each. Group 1 served as negative control (not treated), groups 2 to 5 were experimental groups and were administered $20 \%, 40 \%, 60 \%$ and $80 \%$ of the $\mathrm{LD}_{50}(31 \mathrm{mg}, 62 \mathrm{mg}$, 93mg and $124 \mathrm{mg})$, while group 6 served as positive control (treated with artesunate). The mice were treated orally for seven consecutive days once daily. The results showed that the saturated butanol has anti-plasmodial activity in mice with percentage parasitemia inhibition of $50.6 \%, 80.8 \%, 100 \%, 100 \%$ and $100 \%$ for groups 2 to 5 and artesunate respectively. The results suggest that the plant have potential for the development of a novel anti-malarial agent.

Keywords: Malaria, Methanol, Ficus sycomorus, root and parasitemia.

Copyright @ 2020: This is an open-access article distributed under the terms of the Creative Commons Attribution license which permits unrestricted use, distribution, and reproduction in any medium for non-commercial use (NonCommercial, or CC-BY-NC) provided the original author and source are credited.

\section{INTRODUCTION}

Malaria is a mosquito-borne infectious disease of humans and other animals caused by parasitic protozoan of the Plasmodium family [1]. It is commonly transmitted by the bite of an infected female Anopheles mosquito [2]. The bite introduces the parasites from the mosquito's saliva into a person's blood. In the human body, the parasites multiply in the liver, and then erythrocytes [3, 2]. Symptoms include fever, fatigue, vomiting and headaches, in severe cases it can cause yellow skin, seizures, coma or death [4].

Malaria has proved to be one of the most debilitating illnesses of all time and is the most common parasitic disease in sub-Saharan Africa [5]. Globally, death associated with malaria is highest in Africa and most vulnerable group in the endemic areas is the people in the rural environment who often have little or no access to modern medicine [6]. It is estimated that $1-2$ million people die yearly as a result of malaria [6]. It is the single most important cause of ill health, death and poverty in Sub-Saharan Africa [7]. The situation is further complicated by the worldwide emergence and rapid spread of resistance to several existing anti-malarial by Plasmodium falciparum that threatens to increase the annual death toll by malaria [8].

The use of medicinal plants to treat diseases is as old as man he and medicinal plants have been used since ancient times to treat many illnesses [9]. Herbal medicine was the sole medical system for health care before the advent of orthodox or modern medicine [10]. Even in this present technological era, traditional medicine play a predominant role in the third world for the preservation of health of the rural majority who constitute over $70 \%$ of the total population [10]. The use of traditional remedies is common in sub-Saharan Africa, and visits to traditional healers remain a mainstay of care for many people because of preference, affordability, and limited access to hospitals and modern health practitioners [11]. 
Studies have shown that many medicinal plants contained antioxidant compounds and these antioxidant compounds possess anti-inflammatory, antiatherosclerotic, antitumor, antimutagenic, anticarcinogenic, antibacterial, antiparasitic, antifungal and antiviral activities [12]. The search for antimalarial drug from plant origin cannot be neglected since the antimalarial drugs in use today (quinine and artemisinin) were isolated from plants sources [13].

\section{Materials ANd Methods}

\section{Chemicals and Reagents}

All chemicals and reagents used in this study are of analytical grade

\section{Ficus Sycomorus Plant}

Ficus sycomorus (fruits, leaves, stem-bark and roots) was obtained from Sokoto metropolis, Sokoto State, Nigeria. The plant was identified at the Department of Biological Sciences, Usmanu Danfodiyo University, and Sokoto, Nigeria. A voucher specimen number was obtained (UDUH/ANS/0214) and specimen deposited at the herbarium.

\section{Animals}

Albino mice and rats were obtained from the Animal House of the Department of Biochemistry and Faculty of Sciences Usmanu DanFodiyo University, Sokoto, Nigeria respectively. The animals were housed in standard cages in Animal House, Department of Biochemistry. The animals were allowed access to feed and clean water ad libitum for seven days to acclimatize before commencement of research.

\section{Malaria Parasites \\ Plasmodium falciparum}

Plasmodium falciparum was obtained from Microbiology laboratory, College of Health Sciences (City Campus), Usmanu Danfdiyo University, Sokoto Nigeria.

\section{Plasmodium berghei}

Plasmodium berghei was obtained from Animal House of the Faculty of Pharmaceutical Sciences, Ahmadu Bello University, Zaria Nigeria. Blood from infected mouse was collected through the eyes, diluted in saline and $0.2 \mathrm{ml}$ was intraperitoneal passaged to three mice. The mice were transported in a small cage to the Animal House of the Biochemistry Department, Usmanu Danfodiyo University, Sokoto, Nigeria

Percentage parasitaemia (\%)

$$
=\frac{\text { Total No.of PRBC }}{\text { Total No.RBC Viewed }} \times 100
$$$$
=\frac{\text { PRBCs }}{1000} \times 100
$$

\section{Preparation of the Plant Methanol Extracts}

The four parts of the plant (fruits, leaves, stembark, and roots) were prepared into powdered form using pestle and mortar and then stored in plastic containers for subsequent use under room temperature. Two hundred (200) grams of each of the powdered samples (fruits, leaves, stem-bark, and roots) were soaked in $500 \mathrm{ml}$ of methanol for seventy two (72) hours and stirred occasionally. They were filtered with a clean muslin cloth, and the filtrates were evaporated to dryness using rotary evaporator at $45^{\circ} \mathrm{C}$. The recovered methanol extracts (filtrates) were stored in plastics containers and kept under room temperature.

\section{In vitro Anti-plasmodial Activity methanol crude extracts of the various part Ficus Sycomorus \\ Plasmodium falciparum was used for the in} vitro anti-plasmodial activity of the methanol extracts (fruits, leaves, stem-bark and roots) $30 \mathrm{mg}, 60 \mathrm{mg}, 90$ $\mathrm{mg}, 120 \mathrm{mg}$ and $30 \mathrm{mg}$ of artesunate were dissolved in $4.5 \mathrm{ml}$ distilled water and allow to fully dissolve for twelve [12] hours. These were used for the antiplamsodial activity assay. Drug sensitivity assay was carried out on 96-well microtiter plates. One hundred $(100 \mu \mathrm{L})$ of the culture was placed in each well of the plate, $30 \mu \mathrm{L}$ of the different extracts and artesunate were added to the wells and the positive control, while the negative control contained no treatment $(46.5 \mu \mathrm{g}, 93 \mu \mathrm{g}$, $139.5 \mu \mathrm{g}, 186 \mu \mathrm{g}$ and $46.5 \mu \mathrm{g}$ respectively). The plate was placed in a candle jar and incubated at $37^{\circ} \mathrm{C}$ for 24 hours [14].

After 24 hours, blood from each well was harvested and thin film was prepared for each concentration. The slide was dried under room temperature and fixed by immersing in methanol. The slide was stained with $10 \%$ Giemsa for 20 minutes and washed with distilled water to remove excess stain. It was then dried and observed under the microscope [15]. An area of stained thin blood film where the red blood cells (RBCs) were evenly distributed was observed using X 100 objective (under oil immersion) [15]. Approximately $200 \mathrm{RBCs}$ were counted and the numbers of infected RBCs amongst the 200 RBCs were also counted. The slide was moved to adjacent fields and counting was continued as mentioned earlier. Counting was continued until 5 fields were viewed and1000 erythrocytes were counted [14]. The percentage parasitaemia was calculated by counting the number of parasitized red cells in 1000 cells in a thin blood film $[15,16]$.

Where; PRBC: Parasitized red blood cells and RBC: red blood cells. 
Growth inhibition for each concentration for the extracts was determined by percentage reduction of parasitemia in treated well compared with untreated well or negative control [16].

Growth inhibition $=\quad \frac{\text { PRBCs in Negative Control }- \text { PRBCs in Treated well }}{\text { PRBCs in Negative Control }} \times 100[16]$.

\section{In vitro Anti-Plasmodial Activity of the Organic Solvent Extracts of the Roots \\ The methanol root extract was fractionated} with three organic solvents (Hexane, ethyacetate and saturated butanol) and in vitro anti-plasmodial activity for the solvent extracts was carried out following procedure and concentrations as above. Percentage parasitemia and growth inhibition were calculated following same methods as above.

\section{In vivo Anti-plasmodial Activity of Saturated butanol root extract of Ficus sycomorus}

Saturated butanol extract was used for the invivo anti-plasmodial activity in mice using Plasmodium berghei.

\section{Inoculation of the experimental animals (Mice)}

After acclimatization, thirty (30) mice were inoculated with the parasitized donor erythrocytes containing Plasmodium berghei. Each mouse was injected $0.2 \mathrm{ml}$ of the infected blood intraperitoneal using $1 \mathrm{ml}$ syringe [17]. One week after parasite inoculation, the animals were randomly distributed into six groups of five mice per group and were used for the experiment.

\section{Administration of the Saturated Butanol Extract \\ The thirty (30) infected mice were distributed into six (6) groups (1-6). Group 1 served as negative control, groups 2 to 5 were experimental groups while group 6 served as positive control $[8,15,18]$. Animals in group 6 were treated with orthodox anti-malarial drug (artesunate) for the test period. Group 1 were treated with artesunate, groups 2 to 5 were treated with different concentrations of the saturated butanol extract as percentage of the $\mathrm{LD}_{50} ; 20 \%, 40 \%, 60 \%$ and $80 \%$ of the $\mathrm{LD}_{50}$ for 7 days being the usual practice for traditional medicine $(31 \mathrm{mg}, 62 \mathrm{mg}, 93 \mathrm{mg}$ and $124 \mathrm{mg}$ ) while Group 6 were given normal saline throughout the period of the study. The animals were treated for seven consecutive days once daily by administering the extract orally using cannula.}

\section{Estimation of Parasitemia after the Treatment}

Twenty four (24) hours after the treatment, blood was collected from the tail of each mouse and smeared on to a microscope slide to make a film. A drop of the blood $(3 \mu \mathrm{L})$ was placed on one end of the slide it was smeared across with the help of another slide where a thin film was produced. The slide was dried under room temperature and fixed by immersing in methanol. The slide was stained with $10 \%$ Giemsa for 20 minutes and washed with distilled water to remove excess stain. It was then dried and observed under the microscope [15].

An area of stained thin blood film where the red blood cells (RBCs) were evenly distributed was observed using X 100 objective (under oil immersion) [15]. Approximately 200 RBCs were counted and the numbers of infected RBCs amongst the $200 \mathrm{RBCs}$ were also counted. The slide was moved to adjacent fields and counting was continued as mentioned earlier. Counting was continued until 5 fields were viewed and 1000 erythrocytes were counted [11]. The recommended procedure for estimating the percentage parasitaemia in a thin blood film is by expressing the number of infected cells as a percentage of the red blood cells. The percentage parasitaemia was calculated by counting the number of parasitised red cells in 1000 cells in a thin blood film [15].

Growth inhibition for saturated butanol extract in mice was determined by percentage reduction of parasitemia in treated mice compared with untreated mice or negative control [16]. Percentage parasitemia and growth inhibition were calculated using same methods as above.

\section{RESULTS}

In vitro Anti-plasmodial Activity of the Methanol Extracts of the Four Parts of the Ficus sycomorus

Table 1 showed the in-vitro anti-plasmodial activity assay for the four parts of the Ficus sycomorus (Fruits, Leaves, Stem-Bark and Roots), the negative control and the positive control for comparism. The assay revealed that methanol extracts of the fruits and leaves have little anti-plasmodial activity with leaves extract having more activity than the fruits extract. The methanol extract of the stem-bark and the roots have the highest anti-plasmodial activity, for all parasites were cleared from the least concentration of extracts. Table 1 presents $\mathrm{The} \mathrm{IC}_{50}$ values for the four parts of the plant (fruits, leaves, stem-bark and root) are presented in table 1 . The concentrations used for the fruit and leaves extracts only achieved $19.8 \%$ and $39.6 \%$ growth inhibition $\left(\mathrm{IC}_{50}\right.$ greater than $\left.186 \mu \mathrm{g}\right)$. Fifty percent $(50 \%)$ growth inhibition was achieved at $20.4 \mu \mathrm{g}$ for stem-bark and roots extracts. 
Table-1: In vitro Anti-plasmodial Activities of the Methanol Extracts of the Four Parts of the Ficus sycomorus

\begin{tabular}{|l|c|c|c|}
\hline Plant Part Used & Extract & \% Yield of Extract $(\mathbf{g})$ & $\mathbf{I C}_{\mathbf{5 0}}(\boldsymbol{\mu g})$ \\
\hline Fruits & Methanol & 7.2 & $>186$ \\
\hline Leaves & Methanol & 7.5 & $>186$ \\
\hline Stem-Back & Methanol & 5.2 & 20.4 \\
\hline Roots & Methanol & 4.5 & 20.4 \\
\hline Artesunate & - & - & $>11.5$ \\
\hline
\end{tabular}

$\mathrm{IC}_{50}$ for fruits and leaves are greater than $186 \mu \mathrm{g}(>186 \mu \mathrm{g})$ and stem-bark and roots have $\mathrm{IC}_{50}$ of $20.4 \mu \mathrm{g}$ each.

Table 2 showed phytochemical components of the methanol extracts of the stem-bark and root of the Ficus sycomorus. The analysis revealed the presence of alkaloids, tannins, anthraquinones, saponins, balsams and steroids in both stem-bark and root extracts.
However, cardiacglycosides and saponins are only present in stem-bark while glycosides are only present in the root. Flavonoid, volatile oils are not found in both extracts.

Table-2: Qualitative and Quantitative Phytochemical Contents of Ficus sycomorus Root and Stem-Bark Methanol Extracts

\begin{tabular}{|l|c|c|c|c|}
\hline \multirow{2}{*}{ Phytochemical Components } & \multicolumn{4}{|c|}{ Plant Extracts } \\
\cline { 2 - 5 } & \multicolumn{2}{|c|}{ Qualitative } & \multicolumn{2}{c|}{ Quantitative Concentration (w/w) } \\
\cline { 2 - 5 } & Stem-bark & Roots & Stem-bark & Roots \\
\hline Flavonoid & ND & ND & - & - \\
\hline Tannins & +++ & ++ & 2.40 & 1.48 \\
\hline Saponins & +++ & ++ & 1.00 & 0.80 \\
\hline Glycosides & ND & ++ & - & 1.78 \\
\hline Alkaloids & ++ & ++ & 1.89 & \\
\hline Cardiac Glycosides & + & ND & & 0.88 \\
\hline Steroids & + & + & 1.51 & - \\
\hline Saponin Glycosides & + & ND & 0.56 & - \\
\hline Balsams & ++ & + & - & 0.50 \\
\hline Anthraquinones & ++ & +++ & 0.21 & - \\
\hline Volatile Oils & ND & ND & - & \\
\hline
\end{tabular}

KEY: ND = Not detected. + = Presence in trace amount. ++ = little amount. +++ = large amount

In vitro Anti-plasmodial Activities of Organic Solvents Methanol roots extract (Hexane, ethylacetate and saturated butanol)

In vitro anti-plasmodial activity assay for the three organic solvent extracts (Hexane, Ethylacetate and saturated butanol) percentage yield and $\mathrm{IC}_{50}$ for the solvent extracts are presented in table 3. Hexane extract achieved $50 \%$ growth inhibition at $40 \mu \mathrm{g}$ concentration, ethylacetate achieved growth inhibition of $50 \%$ at $20.4 \mu \mathrm{g}$ concentration and saturated butanol achieved $50 \%$ growth inhibition at $20.4 \mu \mathrm{g}$.

Table-3: In vitro Anti-plasmodial Activities of Organic Solvent Methanol Roots Extracts (Hexane, ethylacetate and saturated butanol)

\begin{tabular}{|l|l|c|c|}
\hline Plant Part Used & Extract & \% Yield of the Extract $(\mathbf{g})$ & $\mathbf{I C}_{\mathbf{5 0}}(\boldsymbol{\mu g})$ \\
\hline Roots & Hexane & 5.5 & 40 \\
\hline Roots & Ethylacetate & 4.0 & 20.4 \\
\hline Roots & Saturated butanol & 3.7 & 20.4 \\
\hline Artesunate & - & - & $>11.5$ \\
\hline
\end{tabular}

Percentage yield for the solvent extract are 5.5g, $4 \mathrm{~g}$ and $3.7 \mathrm{~g}$ for hexane, ethylacetate and saturated butanol respectively. Hexane has $\mathrm{IC}_{50}$ value of $40 \mu \mathrm{g}$. Ethylacetate has $\mathrm{IC}_{50}$ value of $20.4 \mu \mathrm{g}$ concentration. Saturated butanol has $\mathrm{IC}_{50}$ value of $20.4 \mu \mathrm{g}$.

In vivo Anti-plasmodial Activity of the Saturated Butanol Extract of the Ficus sycomorusin albino Mice

Table 4 showed the in vivo anti-plasmodial activity of the different concentrations of the saturated butanol extract of the Ficus sycomorus used in the experimental groups, percentage parasitemia inhibition for experimental groups positive control group. 
Abbas AY et al; Saudi J Med Pharm Sci, March., 2020; 6(3): 315-320

Table-4: In vivo Anti-plasmodial Activity of the Saturated Butanol Extract of the Ficus sycomorus in albino Mice

\begin{tabular}{|c|c|c|}
\hline Groups & Concentration of Extract $\left.\mathbf{( \% ~} \mathbf{~ L D ~}_{\mathbf{5 0}} / \mathbf{m g}\right)$ & \% Parasitemia Inhibition \\
\hline I & $20 \%(31)$ & $50.6 \%$ \\
\hline II & $40 \%(62)$ & $80.8 \%$ \\
\hline III & $60 \%(93)$ & $100 \%$ \\
\hline IV & $80 \%(124)$ & $100 \%$ \\
\hline V & Artesunate (20) & $100 \%$ \\
\hline
\end{tabular}

The percentage parasitemia inhibition against concentration of extract in mg. $20 \%$ and $40 \% \mathrm{LD}_{50}$ achieved $50.6 \%$ and $80.8 \%$ and $60 \%, 80 \%$ and artesunate achieved $100 \%$ inhibition.

\section{DisCUSSION}

The $\mathrm{IC}_{50}$ values for the in vitro anti-plasmodial activity of the Ficus sycomorus revealed that all parts of the plant have anti-plasmodial property however extracts of the fruits and leaves showed that $\mathrm{IC}_{50}$ is greater $(>186 \mu \mathrm{g})$, stem-bark and roots have $\mathrm{IC}_{50}$ values of $20.4 \mu \mathrm{g}$ each. The solvent extracts also showed antiplasmodial property with the $\mathrm{IC}_{50}$ values of $40 \mu \mathrm{g}$ for hexane and $20.4 \mu \mathrm{g}$ for ethylacetate and saturated butanol. The In vivo anti-plasmodial activity of saturated butanol extract in mice showed IC50 values of $31 \mathrm{mg}$ being the $20 \% \mathrm{LD}_{50}$. The percentage parasitemia inhibition indicated that the saturated butanol in mice achieved $50 \%$ growth inhibition at $20 \% \mathrm{LD}_{50}(31 \mathrm{mg})$ concentration and $100 \%$ growth inhibition at $60 \%$ of the $\mathrm{LD}_{50}$. The phytochemical composition of the plant is important, containing alkaloid, balsams, anthraquinones, cardiac glycosides, saponins, tannins, saponin glycosides, steroids and glycosides. The high preponderance of these phytochemicals may be responsible for the antimalarial activity exhibited by the plant [15].These results suggest that there could be scientific merit in the folkloric use of Fycus sycomorus in the management of microbial diseases in the northern part of Nigeria.

Some bioactive compounds have been identified to be present in the Ficus species (Table 2) such as tannins, saponins, flavonoids, alkaloid, steroids, anthraquinone, glycosides, and reducing sugars. Several plant constituents like, flavonoids, tannins, quinonoid, xanthene, polyphenols, and terpenoids have been reported to possess protein-binding and enzymeinhibiting properties. Based on the foregoing, it is suggest that a likely mechanism of action of this plant may be the inhibition of key pathogenic enzymes of the malaria parasite since these bio-compounds are known to interfere with enzyme systems [19].

\section{Conclusion}

The qualitative phytochemical constituents of the Ficus sycomorus indicated the presence of secondary metabolites such as tannins, saponnins, alkaloids, saponins glycosides, steroids, cardiac glycosides and glycosides all of which are known to be pharmacologically active. The study established that the methanol extracts of the stem-bark and root exhibited the highest in vitro anti-plasmodial activity, and when the roots extract was partitioned, saturated butanol extract exhibited the highest anti-plasmodial activity. The in vitro activity of the extract was confirmed by in vivo study. The results suggest that the satured butanol extract of the plant could serve as source of novel anti-plasmodial agent(s) that can be used to develop an anti-malarial drug.

\section{REFERENCES}

1. Omosun, G., Okoro, I. A., Ekundayo, E., Ojimelukwe, P. C., \& Ibe, O. (2013). Ethnobotanical study of medicinal plants useful for malaria therapy in eight local government areas of Abia State, Southeast Nigeria. Advancement in Medicinal Plant Research, 1(2), 39-44.

2. Adumanya, O. C. U., Osuji, C. N., Obi-Adumanya, G. A., \& Akunna, T. O. (2013). Antiplasmodial effect of some medicinal plants (Picralima nitida and Dialium guineense) and their combination with artesunate. Int. JA PS. BMS, 2(4), 189-194.

3. Odugbemi, T. O., Akinsulire, O. R., Aibinu, I. E., \& Fabeku, P. O. (2007). Medicinal plants useful for malaria therapy in Okeigbo, Ondo State, Southwest Nigeria. African Journal of Traditional, Complementary and Alternative Medicines, 4(2), 191-198.

4. Baird, J. K., \& Hoffman, S. L. (2004). Primaquine therapy for malaria. Clinical infectious diseases, 39(9), 1336-1345.

5. Kazembe, T., Munyarari, E., \& Charumbira, I. (2012). Use of traditional herbal medicines to cure malaria. Bulletin of Environment, Pharmacology and Life Sciences, 1(4), 63-85.

6. Idowu, O. A., Soniran, O. T., Ajana, O., \& Aworinde, D. O. (2010). Ethnobotanical survey of antimalarial plants used in Ogun State, Southwest Nigeria. African Journal of Pharmacy and Pharmacology, 4(2), 055-060.

7. Sanon, S., Gansane, A., Ouattara, L. P., Traore, A., Ouedraogo, I. N., Tiono, A., ... \& Sirima, S. B. (2013). In vitro antiplasmodial and cytotoxic properties of some medicinal plants from western Burkina Faso. African journal of laboratory medicine, 2(1).

8. Khan, M. E., Toma, I., Shingu, D. Y., \& Wazis, C. H. (2012). Antiplasmodial activity of the methanol extract of the roots of Aristolochia albida in Albino Swiss mice. J Biol Sci Bioconserv, 4, 26-38. 
9. Anthoney, S. T., Ngule, C. M., \& Obey, J. (2013). Phytochemical analysis of Vernonia adoensis leaves and roots used as a traditional medicinal plant in Kenya. International Journal of Pharmacy and Biological Sciences, 3(3), 2230-7605.

10. Okoli, R. I., Aigbe, O., Ohaju-Obodo, J. O., \& Mensah, J. K. (2007). Medicinal herbs used for managing some common ailments among Esan people of Edo State, Nigeria. Pakistan Journal of Nutrition, 6(5), 490-496.

11. Njan, A. A. (2012). Herbal medicine in the treatment of malaria: Vernonia amygdalina: an overview of evidence and pharmacology. Toxicity and Drug Testing, 167-186.

12. Kumar, M., Faheem, M., Singh, S., Shahzad, A., \& Bhargava, A. K. (2013). Antifungal activity of the Carica papaya important food and drug plant. Asian Journal of Plant Science and Research, 3(1), 8386.

13. Omoya, F. O., \& Momoh, A. O. (2014). The Efficacy of Andrographis paniculata and Chromolena odorata plant extracts against Malaria parasite. International Journal of Biological, Life Science and Engineering, 8(5), 134-137.

14. Biradar, Y. S. (2009). In vitro Cultivation of Plasmodium
Shodhganga.inflibnet.ac.in > 07-chapter 2. Accessed December, 2019

15. Pascal, R., Fleurette, S. M., Jean, B. and Leonard, K. B. (1999). In vitro Culture and Drug Sensitivity Assay of Plasmodium falciparum with non-Serum Substitute and Acute-Phase. Journal of Clinical Microbiology

16. de Madureira, M. D. C., Martins, A. P., Gomes, M., Paiva, J., da Cunha, A. P., \& do Rosário, V. (2002). Antimalarial activity of medicinal plants used in traditional medicine in S. Tomé and Principe islands. Journal of Ethnopharmacology, 81(1), 23-29.

17. Adebajo, A. C., Odediran, S. A., Aliyu, F. A., Nwafor, P. A., Nwoko, N. T., \& Umana, U. S. (2014). In vivo antiplasmodial potentials of the combinations of four Nigerian antimalarial plants. Molecules, 19(9), 13136-13146.

18. Adebayo-Tayo, B. C., \& Odeniyi, A. O. (2012). Phytochemical screening and microbial inhibitory activities of Ficus Capensis. African journal of biomedical research, 15(1), 35-40.

19. Shittu, I. I., Emmanuel, A., \& Nok, A. J. (2011). Antimalaria effect of the ethanolic stem bark extracts of Ficus platyphylla Del. Journal of parasitology research, 2011 